\section{Magnetotactic bacteria as a new model for $P$ sequestration in the ferruginous Lake Pavin}

\author{
S. Rivas-Lamelo1, K. Benzerara ${ }^{1 *}$, C.T. Lefèvre ${ }^{2}$, C.L. Monteil ${ }^{2}$, \\ D. Jézéquel ${ }^{3}$, N. Menguy ${ }^{1}$, E. Viollier ${ }^{3}$, F. Guyot ${ }^{1}$, C. Férard ${ }^{1}$, M. Poinsot ${ }^{1}$, \\ F. Skouri-Panet ${ }^{1}$, N. Trcera ${ }^{4}$, J. Miot ${ }^{1}$, E. Duprat ${ }^{1}$
}

Abstract

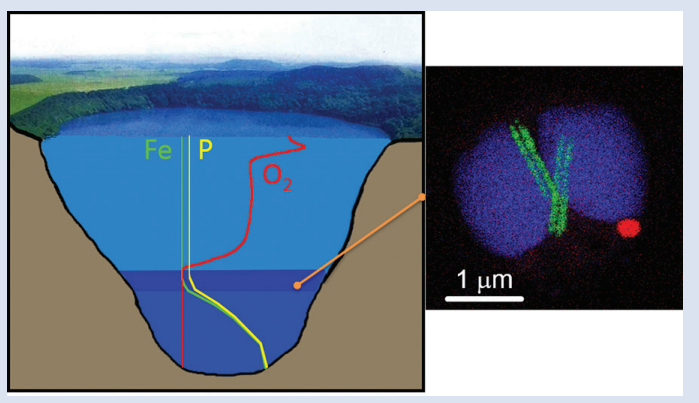

The role of microorganisms in the geochemical cycle of $\mathrm{P}$ has received great interest in the context of enhanced biological phosphorus removal and phosphorite formation. Here, we combine scanning and transmission electron microscopies, confocal laser scanning microscopy and synchrotron-based $x$-ray microfluorescence to analyse the distribution of $\mathrm{P}$ at the oxic-anoxic interface in the water column of the ferruginous Lake Pavin. We show that magnetotactic bacteria of the Magnetococcaceae family strongly accumulate polyphosphates and appear as $\mathrm{P}$ hotspots in the particulate fraction at this depth. This high accumulation may be characteristic of this family and may also relate to the chemical conditions prevailing in the lake. As a result, these magnetotactic cocci can be considered as new models playing a potentially important role in the $\mathrm{P}$ geochemical cycle, similar to sulphide oxidising bacteria such as Thiomargarita and Beggiatoa but thriving in a ferruginous, poorly sulphidic environment.

Received 2 June 2017 | Accepted 10 October 2017 | Published 15 November 2017

\section{Introduction}

Magnetotactic bacteria (MTB) are a phylogenetically and metabolically diverse group of bacteria biomineralising intracellular magnetites and/or greigites and moving along magnetic field lines. Since their discovery (Blakemore, 1975), they have been found in various environments worldwide including sediments and the water column of freshwater, marine and hypersaline habitats (Lefèvre and Bazylinski, 2013). Their abundance usually peaks at the oxic/anoxic boundary and they have been shown to be the dominant bacteria in some environments (e.g., Spring et al., 1993; Simmons et al., 2007). They have received much attention in the context of the search for ancient traces of life (e.g., Li et al., 2013). They sometimes contribute significantly to the sediment magnetic signal (Chen et al., 2014). However, their effective impact on geochemical cycles has been rarely assessed (Lin et al., 2014) except in a study by Chen et al. (2014) suggesting that MTB-associated Fe may provide a significant iron flux in some euxinic systems.

Lake Pavin is a permanently stratified (meromictic) crater lake with a maximum depth of $92 \mathrm{~m}$. The oxic/anoxic boundary is located within the water column, shifting in depth between $\sim 50$ to $\sim 65 \mathrm{~m}$ depending on the efficiency of water mixing (Michard et al., 1994). In contrast with many permanently stratified water bodies which are euxinic below their chemocline, the monimolimnion of Lake Pavin is ferruginous, i.e. sulphide-poor ( $<20 \mu \mathrm{M}$; Bura-Nakic et al., 2009) and Fe(II)rich (up to $1200 \mu \mathrm{M}$; Busigny et al., 2016). The P and Fe cycles are tightly coupled in the anoxic zone through precipitation of Fe phosphates, which impacts the concentration of dissolved $\mathrm{P}$ in the deep anoxic waters (Cosmidis et al., 2014; Fig. S-1).

Strong chemical gradients in the water column of Lake Pavin (Fig. S-1) parallel a broad diversity of mineral phases associated with microorganisms, including MTB (Miot et al., 2016). Because the oxic-anoxic interface occurs within the water column of Lake Pavin, it is easily accessible compared to many other aqueous environments, where it is located within the sediments. We therefore studied MTB at the oxic-anoxic interface in Lake Pavin and particularly focused on their association with phosphorus.

\footnotetext{
1. Institut de Minéralogie, de Physique des Matériaux, et de Cosmochimie (IMPMC), Sorbonne Universités, UPMC Université Paris 6, UMR CNRS 7590, Muséum National d'Histoire Naturelle, IRD UMR 206, 4 place Jussieu, 75005 Paris, France

Corresponding author (email: karim.benzerara@upmc.fr)

2. CNRS/CEA/Aix-Marseille Université, UMR7265 Biosciences and Biotechnologies Institute, 13108 Saint Paul lez Durance, France

Institut de Physique du Globe de Paris (IPGP), Sorbonne Paris Cité- Université Paris Diderot, UMR CNRS 7154, 1 rue Jussieu, 75238 Paris cedex 05, France

Synchrotron SOLEIL, Lucia Beamline, 91192 Gif Sur Yvette, France
} 


\section{Results}

MTB cells were detected by optical microscopy in non-sorted and magnetically-sorted samples collected between 53 and $59 \mathrm{~m}$ depth. All MTB-containing samples were collected at a depth where $\mathrm{O}_{2}$ concentration was lower than the detection limit of the probe (Fig. S-1). Over the sampled depth range, total dissolved $\mathrm{Fe}$, DIP and $\mathrm{H}_{2} \mathrm{~S}$ concentrations increased from 0.2 to $\sim 60 \mu \mathrm{M}, 0.3$ to $\sim 20 \mu \mathrm{M}$ and 0 to $\sim 2.5 \mu \mathrm{M}$, respectively. MTB populations reached a maximum concentration of 1.4 $\times 10^{3}$ cells $/ \mathrm{mL}$. This can be compared to the total number of bacterial cells ranging between $2 \times 10^{6}$ and $9 \times 10^{6}$ cells $/ \mathrm{mL}$ in the oxic-anoxic transition zone of Lake Pavin as estimated by Lehours et al. (2005). In the MTB population, small curved rods and large rods were observed, but the majority of MTB cells collected at the oxycline were cocci measuring $\sim 2 \mu \mathrm{m}$ in diameter. Several morphotypes of MTB cocci were observed: the most common contained 1) two chains of cuboctahedral magnetosomes, while some others contained 2) four magnetosome chains or 3) magnetite crystals not aligned as chains
(Fig. 1). Many of these MTB cells contained two other types of electron dense granules: S-rich and P-rich granules. S-granules were not systematically observed, although granules that contained only $\mathrm{S}$ are shown by EDXS and measured up to $\sim 820 \mathrm{~nm}$ in diameter (Fig. S-2). In many MTB cocci, P-rich inclusions filled most of the volume of the cells (Figs. 1, S-2). $\mathrm{P}$-granules contained $\mathrm{Ca}, \mathrm{K}, \mathrm{Mg}$ and $\mathrm{P}$ with varying relative abundances. Some MTB cells contained Mg-rich P-granules with relative abundances of $\mathrm{Mg}, \mathrm{P}, \mathrm{K}$ and $\mathrm{Ca}$ of $22.8 \pm 4,65.9$ $\pm 3.2,5.1 \pm 3.1$ and $6 \pm 5.4$ at. \% $(n=37)$, respectively. Other MTB cells contained $\mathrm{P}$-granules poorer in $\mathrm{Mg}$ and richer in $\mathrm{Ca}$ with relative abundances of $\mathrm{Mg}, \mathrm{P}, \mathrm{K}$ and $\mathrm{Ca}$ of $6.7 \pm 2.5,56 \pm$ $3.4,1.5 \pm 0.7$ and $35.3 \pm 1.9$ at. $\%(n=11)$, respectively. Similar P-granules have been classically interpreted as polyphosphates (polyP), which are linear polymers of orthophosphate linked by high energy phosphoanhydride bonds (Kornberg, 1995). $\mathrm{The}(\mathrm{K}+\mathrm{Mg}+\mathrm{Ca}) / \mathrm{P}$ ratio $(<0.8)$ is suggestive of polyphosphates. Here, this interpretation was confirmed by DAPI staining (Figs. 2, S-3).

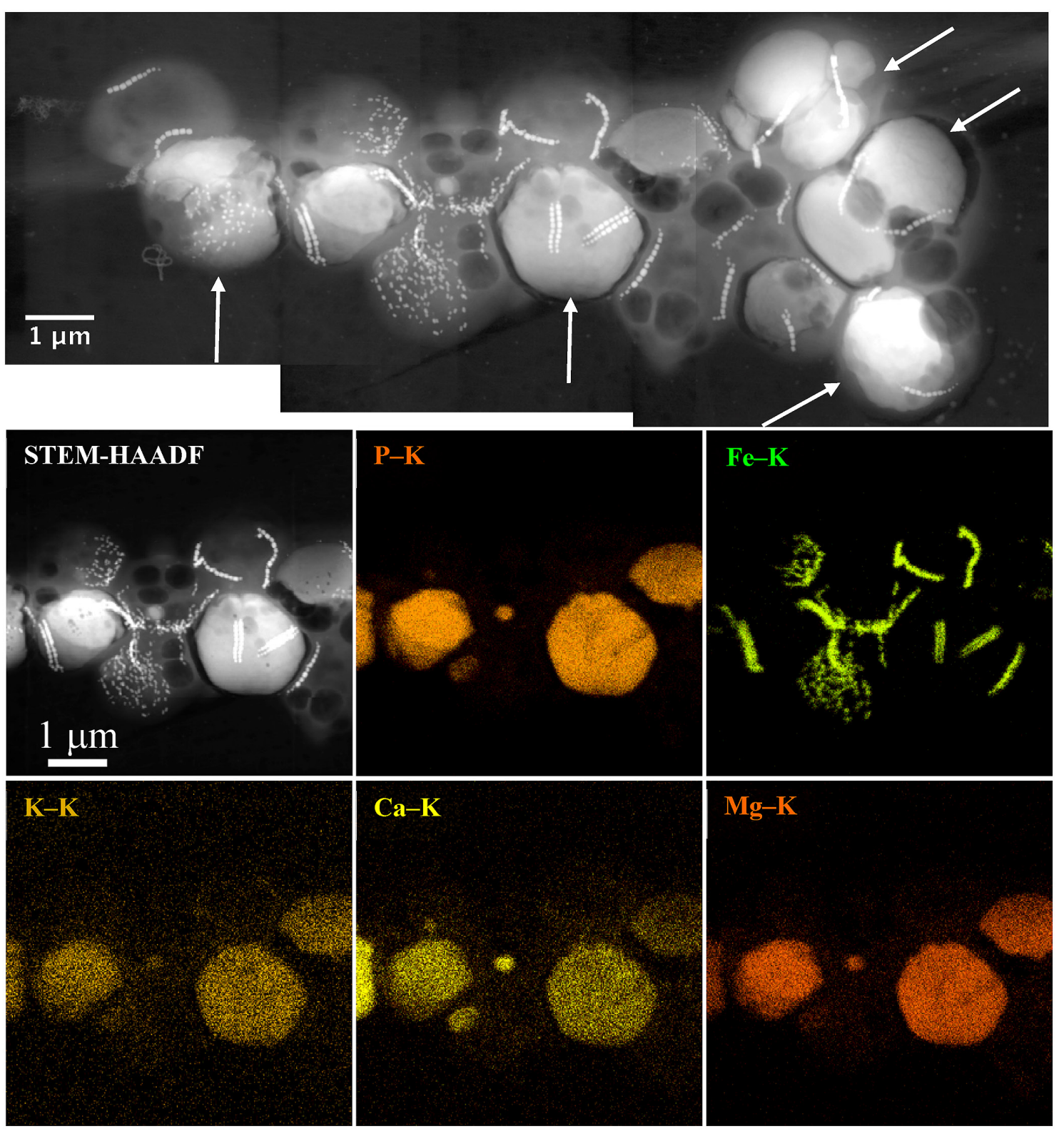

Figure 1 Scanning transmission electron microscopy analyses of MTB cells at the oxic-anoxic interface in Lake Pavin. Top: STEMHAADF image showing a cluster of MTB cells. Magnetites are the brightest particles. Some cells contain two or four magnetite chains; some (bottom left) contain scattered magnetite. Polyphosphates appear as bright granules filling completely some of the cells (e.g., arrows). Bottom: EDXS maps. 


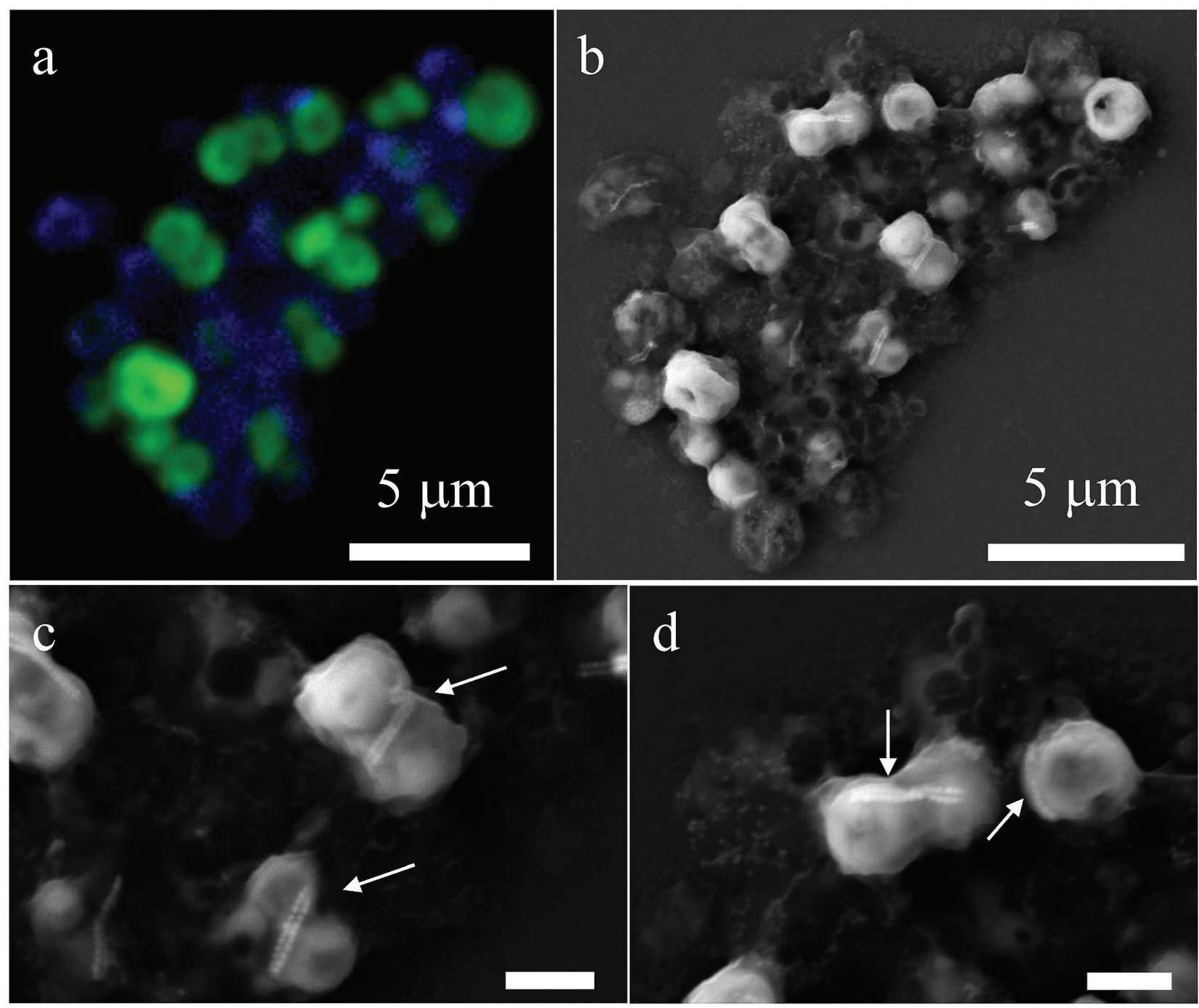

Figure 2 Correlative CLSM-SEM microscopy. (a) Overlay of fluorescence maps of DAPI-stained nucleic acid (blue) and polyphosphate (green). (b) SEM image in secondary electron mode of the same area. Brighter cells are filled with polyphosphates. (c) and (d) Close ups of areas seen in (b). Cells filled with polyphosphates contain bright magnetite chains (arrows). Scale bar is $1 \mu \mathrm{m}$ for (c) and (d).

Phylogenetic analyses revealed that the dominant operational taxonomic units (OTU) from magnetically enriched samples were affiliated to Alphaproteobacteria and more specifically, the Magnetococcaceae family (Fig. 3). Based on a similarity threshold of $99 \%$ on the whole $16 \mathrm{~S}$ rDNA gene sequence for defining species, two different species of magnetotactic cocci were detected. One species (8 clones, accession numbers KX270016-KX270023), represented the most abundant MTB at the oxycline of Lake Pavin. The closest relatives were two magnetotactic cocci (GQ468510 and GQ468517) previously detected in the sediments of Lake Miyun (Beijing, China; Lin et al., 2010). A second species found in smaller proportions (accession number KX270015) was closely related to OTU 13, another magnetotactic coccus detected in Lake Miyun (GQ468512).

In order to better assess the significance of the phosphorus fraction carried by these MTB cells, total particulate matter $(>0.2 \mu \mathrm{m})$ was collected at the Lake Pavin oxic-anoxic interface and analysed by synchrotron-based $\mathrm{x}$-ray microfluorescence (Fig. 4). The integrated fluorescence intensity at each pixel of the $\mathrm{P}$ map was linearly related to the amount of $\mathrm{P}$. We identified 41 areas with high P contents (Fig. S-4). Some areas consisted of a single pixel, whereas others comprised as many as 40 contiguous pixels. All these areas were systematically re-analysed correlatively at higher spatial resolution by SEM. Eight of these P hotspots corresponded to polyP-loaded
MTB cells (Fig. 4b,c,e,g,i-l; Fig. S-4). Four other less intense P hotspots were also polyP-loaded MTB cells (Fig. 4a,d,f,h). All the other $\mathrm{P}$ hotspots were $\mathrm{Fe}$ phosphate precipitates and no other microorganism was detected among these $\mathrm{P}$ hotspots (Fig. S-5). Altogether, the 12 polyP-loaded MTB cells identified by SEM harboured $0.6 \%$ of the total P in the mapped area, which comprises a total of 21,336 pixels. Moreover, the $\mathrm{P}$ content measured on single MTB-containing pixels was between 6- and 23-fold higher than the median per pixel $\mathrm{P}$ content (Fig. S-6), providing a rough assessment of the $\mathrm{P}$ concentration factor in MTB compared to other cells.

\section{Discussion}

Here, we show that some MTB accumulate polyP to a very high level, up to $\sim 23$-fold higher than most microbial cells found at the oxic-anoxic interface in the water column of Lake Pavin. High accumulation of polyP was previously documented for several, non-MTB, bacterial species belonging to Proteobacteria and Actinobacteria (e.g., Nakamura et al., 1995; He and McMahon, 2011). Such bacteria have been considered as critical actors for the removal of excess phosphorus from wastewater (Tarayre et al., 2016) or the formation of marine P-rich sediments called phosphorites (Crosby and Bailey, 2012). 


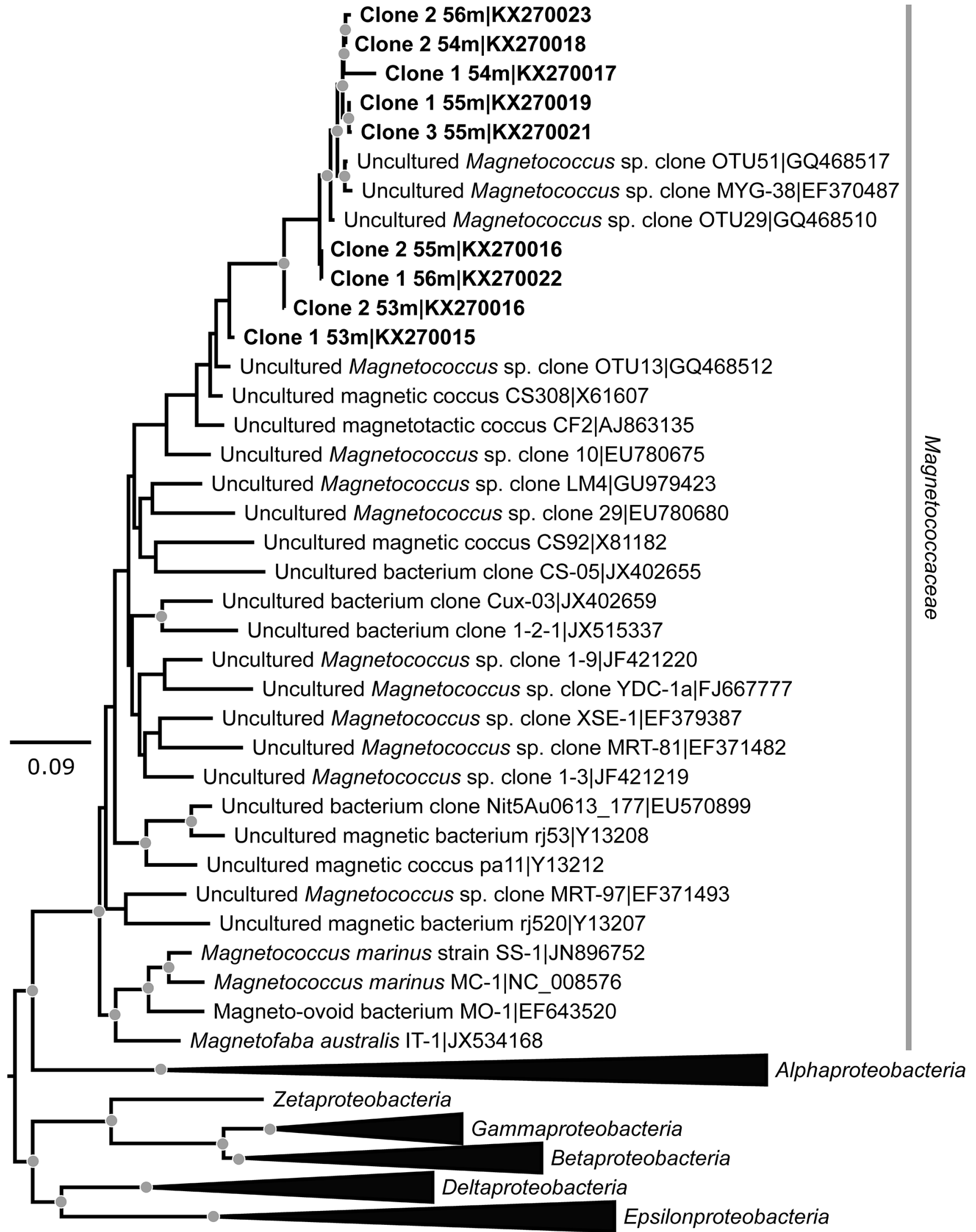

Figure 3 Maximum likelihood phylogenetic tree built based on 16S rDNA gene sequences of MTB clones from Lake Pavin (bold). It includes the closest related Magnetococcaceae found elsewhere. GenBank accession numbers are associated with clones/strains names. Nodes supported by a bootstrap value above $70 \%$ are highlighted by a grey circle. Branch length is proportional to the number of base substitutions per site (see scale bar). 


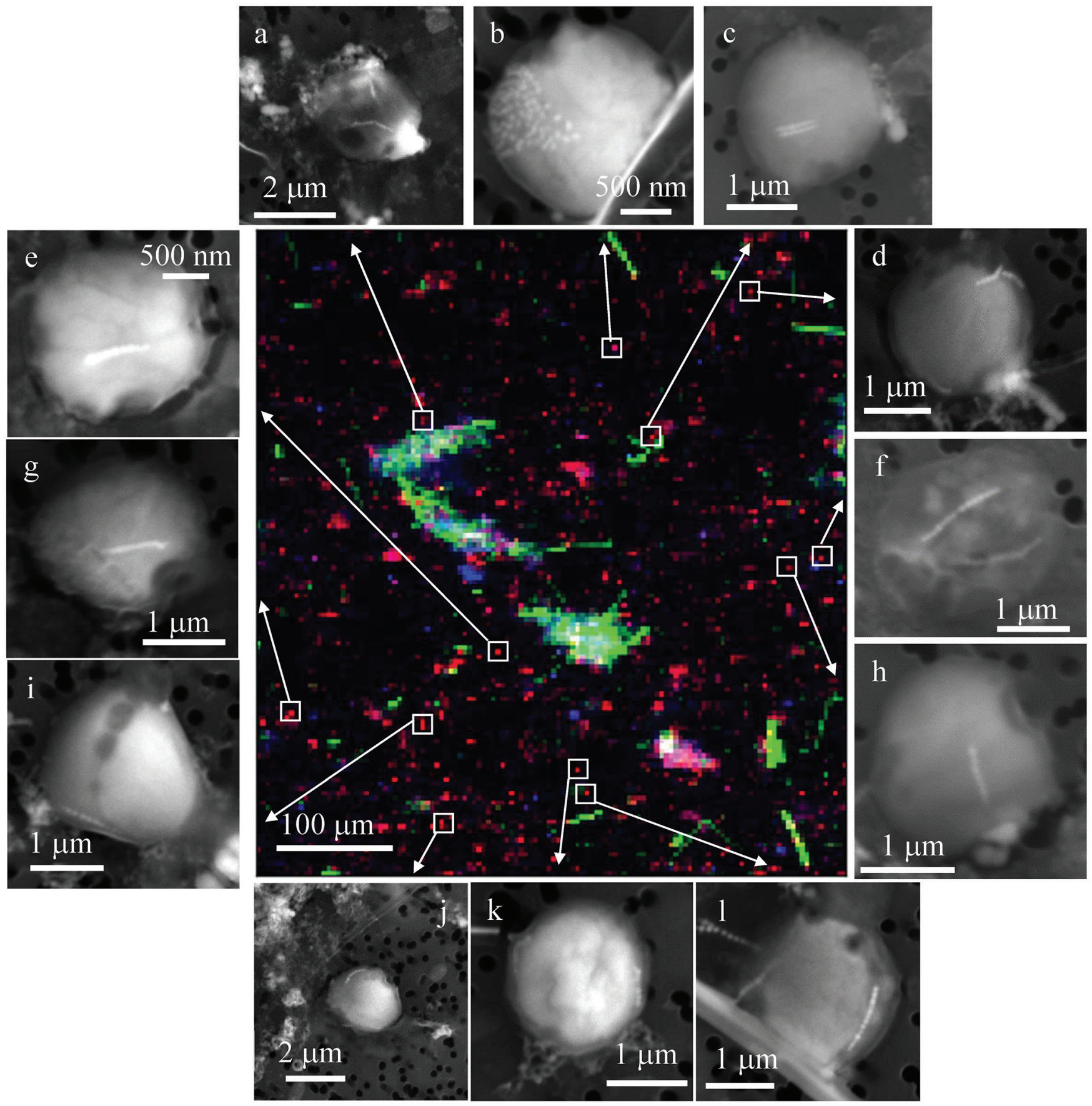

Figure 4 Correlative $\mu$-XRF and SEM microscopy. Centre: XRF maps of P (red), Si (green) and S (blue). The brightest P spots were subsequently imaged by SEM. Many hotspots correspond to polyP-loaded MTB cells as shown in (a) to (I). Other hotspots were almost exclusively Fe phosphate precipitates (Fig. S-5).

Some magnetotactic cocci from Lake Baldwin, California and Itaipu lagoon, Brazil resembling the MTB cells observed in Lake Pavin were also shown to form intracellular polyP inclusions, sometimes occupying a large part of their cell volume (Cox et al., 2005; Keim et al., 2005). This process is even more pronounced in Lake Pavin with some Magnetococcaceae cells fully filled with polyP. Here, the ability of these cells to swim along the magnetic field lines during magnetic enrichment procedures suggests that they stay viable.

Several functions have been suggested for polyP inclusions such as a source of ATP, or a response to oxidative stress (Seviour et al., 2003). MTB cells containing large amounts of polyP in Lake Pavin were detected at depths where low extracellular P concentrations $(\sim 0.7 \mu \mathrm{M}$ at $54 \mathrm{~m})$ were measured Several environmental conditions have been shown to stimulate polyP accumulation/hydrolysis (e.g., Brock and Schulz-Vogt, 2011). Firstly, in wastewater treatments, addition of fatty acids or acetate under anoxic conditions triggers phosphate release by some polyP-concentrating bacteria (Comeau et al., 1986), while these bacteria accumulate polyP under oxic conditions (e.g., Karl et al., 2014). Oxic-anoxic cycles induce high polyP accumulation in these bacteria. Lake Pavin Magnetococcaceae may massively accumulate polyP by experiencing similar oxic/anoxic fluctuations, either by travelling vertically over short distances from the oxic to anoxic zone (and vice versa), or by being affected by seasonal depth shifts of the oxic/ anoxic boundary. Accumulation and hydrolysis of polyP may affect cell buoyancy as shown for other bacteria (Romans et al., 1994) and favour downward movements after accumulation. Secondly, and alternatively, addition of sulphide under anoxic conditions triggers phosphate release by the sulphoxidising 
bacteria Beggiatoa and Thiomargarita (Brock and Schulz-Vogt, 2011), while these bacteria accumulate and keep high polyP contents under oxic conditions and anoxic sulphide-poor conditions. Interestingly, intracellular S-globules in some of Lake Pavin MTB cells suggest that these bacteria are sulphide and/or thiosulphate oxidisers, similar to the closely genetically related cultured Magnetococcus marinus strain MC-1 (Bazylinski et al., 2013). Whether Lake Pavin MTB are affected by sulphides similarly to Beggiatoa will have to be determined. If this is the case, sulphide concentrations are relatively low $(<0.2 \mu \mathrm{M}$ below $58 \mathrm{~m})$ at the depth where Lake Pavin MTB were observed and could be a parameter explaining the high accumulation of polyP in MTB below the oxic/anoxic boundary in Lake Pavin. Analysing the polyP content of MTB cells at different depths throughout these chemical gradients would help in answering this question.

Fe phases were suggested to control the P geochemical cycle in Lake Pavin (Busigny et al., 2016) via high affinity sorption at their surface. Alternatively, involvement of microorganisms in the extracellular precipitation of Fe phosphates has been evidenced (Cosmidis et al., 2014; Miot et al., 2016). Here, MTB also couple the geochemical cycles of $\mathrm{P}$ and Fe through accumulation of two separate Fe and P intracellular reservoirs (polyP and magnetites).

The geochemical impact of polyP-accumulating bacteria has been particularly stressed in the context of wastewater treatment and the formation of phosphorites. In the first case, bacterial genera such as Pseudomonas and Acinetobacter play a predominant role in $\mathrm{P}$ accumulation in $\mathrm{P}$-rich solutions (Nathan et al., 1993). In the case of marine phosphorite formation, sulphoxidising bacteria have become major bacterial models involved in the accumulation of low concentrations of $\mathrm{P}$ from the water column, before release in porewater under anoxic conditions, resulting in the precipitation of apatite-like phases in the sediments (Goldhammer et al., 2010). Microfossils resembling modern sulphoxidising bacteria were evidenced in the geological record, suggesting that they may have played a role in the formation of ancient phosphorites as well (Bailey et al., 2013). Diatoms have been also suspected to be major players in the accumulation of $\mathrm{P}$ as polyP, before release and precipitation of $P$ phases in the sediments (Diaz et al., 2008). Here, we show that Magnetococcaceae appear as new models of polyP-accumulating bacteria in freshwater ferruginous environments. While the reservoir they represent seems modest in size $(<1 \%$ of the total $\mathrm{P})$, it may, similarly to sulphoxidising bacteria in some marine sediments, be dynamic because of active microbially mediated transformations of polyP and may therefore significantly contribute to the $\mathrm{P}$ cycle in this environment. This will be important to assess further in future studies. The relative simplicity by which MTB can be extracted from a suspension by magnetic sorting makes them an interesting tool for concentrating and removing $\mathrm{P}$ from a solution. Moreover, similar to sulphide oxidising bacteria, traces of MTB are tractable in the geological record. Identifying the specific crystallographic, geochemical and/or magnetic properties (e.g., Amor et al., 2016) of their intracellular magnetites provides a perspective to track their potential contribution to the formation of ancient lacustrine phosphorites.

\section{Acknowledgements}

KB has been supported by funding from the European Research Council under the European Community's Seventh Framework Programme (FP7/2007-2013 Grant Agreement no.307110 - ERC CALCYAN). The TEM and SEM facilities at IMPMC were purchased owing to a support by Region Ile-de-France grant SESAME 2000E1435 and 2006Nº-07-593/R. CM and
CL were supported by the French National Research Agency (ANR Tremplin-ERC BIOMAGNET and ANR MEFISTO). ED was supported by the French National Center for Scientific Research (CNRS-INSU program EC2CO). JM was supported by the ANR SRB project, grant ANR-14-CE33-0003-01 of the French Agence Nationale de la Recherche.

Editor: Liane G. Benning

\section{Additional Information}

Supplementary Information accompanies this letter at www. geochemicalperspectivesletters.org/article1743

Reprints and permission information are available online at http://www.geochemicalperspectivesletters.org/ copyright-and-permissions

Cite this letter as: Rivas-Lamelo, S., Benzerara, K., Lefèvre, C.T., Monteil, C.L., Jézéquel, D., Menguy, N., Viollier, E., Guyot, F., Férard, C., Poinsot, M., Skouri-Panet, F., Trcera, N., Miot, J., Duprat, E. (2017) Magnetotactic bacteria as a new model for P sequestration in the ferruginous Lake Pavin. Geochem. Persp. Let. 5, 35-41.

\section{References}

Amor, M., Busigny, V., Louvat, P., Gelabert, A., Cartigny, P., Durand-Dubief, M., Ona-Nguema, G., Alphandery, E., Chebbi, I., Guyot, F. (2016) Mass-dependent and -independent signature of Fe isotopes in magnetotactic bacteria. Science 352, 705-708.

Bailey, J.V., Corsetti, F. A., Greene, S.E, Crosby, C.H., LiU, P., ORPHAN, V.J. (2013) Filamentous sulfur bacteria preserved in modern and ancient phosphatic sediments: implications for the role of oxygen and bacteria in phosphogenesis. Geobiology 11, 397-405.

BazYlinski, D.A., Williams, T.J., Lefèvre, C.T., BerG, R.J., ZhANG, C.L., Bowser, S.S., DeAN, A.J., Beveridge, T.J. (2013) Magnetococcus marinus gen. nov., sp. nov., a marine, magnetotactic bacterium that represents a novel lineage (Magnetococcales ord. nov.) at the base of the Alphaproteobacteria. International Journal of Systematic and Evolutionary Microbiology 63, 801-808.

BLAKEMORE, R. (1975) Magnetotactic bacteria. Science 190, 377-379.

Brock, J., Schulz-Vogt, H.N. (2011) Sulfide induces phosphate release from polyphosphate in cultures of a marine Beggiatoa strain. ISME Journal 5, 497-506.

Bura-Nakice, E., Viollier, E., JézéQuel, D., Thiam, A., Ciglene Ki, I. (2009) Reduced sulfur species in anoxic water column of meromictic Pavin crater lake (Massif Central, France). Chemical Geology 266, 311-317.

Busigny, V., Michard, G., Jézéquel, D., Cosmidis, J., Viollier, E., Benzerara, K., Planavsky, N.J., Albéric, P., Lebeau, O., SARAZIN, G. (2016) The iron wheel in Lac Pavin: interaction with phosphorus cycle. In: Sime-Ngando, T., Boivin, P., Chapron, E., Jezequel, D., Meybeck, M. (Eds.) Lake Pavin. Springer International Publishing, Switzerland, 205-220.

Chen, A.P., Berounsky, V.M., Chan, M.K., Blackford, M.G., Cady, C., Moskowitz, B.M., KraAl, P., Lima, E.A., KopP, R.E., LuMPKIN, G.R., Weiss, B.P., Hesse, P., Vella, N.G.F. (2014) Magnetic properties of uncultivated magnetotactic bacteria and their contribution to a stratified estuary iron cycle. Nature Communications 5, 4797.

Comeau, Y., Hall, K.J., Hancock, R.E.W., Oldham, W.K. (1986) Biochemical-model for enhanced biological phosphorus removal. Water Research 20, 1511-1521.

Cosmidis, J., Benzerara, K., Morin, G., Busigny, V., Lebeau, O., Jézéquel, D., Noël, V., Dublet, G., Othmane, G. (2014) Biomineralization of iron-phosphates in the water column of Lake Pavin (Massif Central, France). Geochimica and Cosmochimica Acta 126, 78-96.

Cox, B.L., Popa, R., Bazylinski, D.A., Lanoil, D., Douglas, S., Belz, A., ENGLER, D.L., NEALSON, K.H. (2002) Organization and elemental analysis of $\mathrm{P}_{-}, \mathrm{S}-$-, and $\mathrm{Fe}-$ rich inclusions in a population of freshwater magnetococci. Geomicrobiology Journal 19, 387-406. 
Crosby, C.H., Bailey, J.V. (2012) The role of microbes in the formation of modern and ancient phosphatic mineral deposits. Frontiers in Microbiology 3, 241.

Diaz, J., Ingall, E., Benitez-Nelson, C., Paterson, D., De Jonge, M.D., MCNulty, I., BRANDES, J.A. (2008). Marine polyphosphate: a key player in geologic phosphorus sequestration. Science 320, 652-655.

Goldhammer, T., Breuchert, V., Ferdelman, T.G., Zabel, M. (2010) Microbial sequestration of phosphorus in anoxic upwelling sediments. Nature Geoscience 3, 557-561.

He, S., McMahon, K.D. (2011) Microbiology of "Candidatus Accumulibacter" in activated sludge. Microbial Biotechnology 4, 603-619.

KARL, D.M. (2014) Microbially Mediated Transformations of Phosphorus in the Sea: New Views of an Old Cycle. Annual Review of Marine Science 6, 279-337.

Keim, C.N., Solorzano, G., Farina, M., Lins, U. (2005) Intracellular inclusions of uncultured magnetotactic bacteria. International Microbiology 8, 111-117.

KORNBERG, A. (1995). Inorganic polyphosphate-toward making a forgotten polymer unforgettable. Journal of Bacteriology 177, 491-496

LefÈVRE, C.T., BAZYLINSKI, D.A. (2013) Ecology, Diversity, and Evolution of Magnetotactic Bacteria. Microbiology and Molecular Biology Reviews $77,497-526$

Lehours, A.C., Bardot, C., Thenot, A., Debroas, D., Fonty, G. (2005) Anaerobic microbial communities in Lake Pavin, a unique meromictic lake in France. Applied and Environmental Microbiology 71, 7389-7400.

Li, J., Benzerara, K., Bernard, S., BeyssaC, O. (2013) The link between biomineralization and fossilization of bacteria: Insights from field and experimental studies. Chemical Geology 359, 49-69.

LIN, W., PAN, Y. (2010) Temporal variation of magnetotactic bacterial communities in two freshwater sediment microcosms. FEMS Microbiology Letters 302, 85-92.

Lin, W., Bazylinski, D.A., XIAO, T., WU, L.F., PAN, Y.X. (2014) Life with compass: diversity and biogeography of magnetotactic bacteria. Environmental Microbiology 16, 2646-2658.

Michard, G., Viollier, E., Jezequel, D., SArazin, G. (1994) Geochemical study of a crater lake - Pavin lake, France - identification, location and quantification of the chemical-reactions in the lake. Chemical Geology $115,103-115$.

Miot, J., Jezequel, D., Benzerara, K., Cordier, L., Rivas-Lamelo, S., Skouri-Panet, F., Ferard, C., Poinsot M., Duprat, E. (2016) Mineralogical diversity in Lake Pavin: connections with water column chemistry and biomineralization processes. Minerals 6, 24 .

NAKamura, K., Hiraishi, A., Yoshimi, Y., KaWAharasaKi, M., Masuda, K., KAMAGATA, Y. (1995) Microlunatus phosphovorus gen. nov., sp. nov., a new gram-positive polyphosphate-accumulating bacterium isolated from activated sludge. International Journal of Systematic and Evolutionary Microbiology 45, 17-22.

Nathan, Y., Bremner, J.M., Lowenthal, R.E., Monteiro, P. (1993) Role of bacteria in phosphorite genesis. Geomicrobiology Journal 11, 69-76.

Romans, K.M., CARPEnter, E.J., Bergman, B. (1994) Buoyancy regulation in the colonial diazotrophic cyanobacterium Trichodesmium tenue: ultrastructure and storage of carbohydrate, polyphosphate, and nitrogen. Journal of Phycology 30, 935-942.

SEviour, R.J., Mino, T., OnUKI, M. (2003) The microbiology of biological phosphorus removal in activated sludge systems. FEMS Microbiology Review 27, 99-127.

Simmons, S.L., BAZYLinski, D.A., Edwards, K.J. (2007) Population dynamics of marine magnetotactic bacteria in a meromictic salt pond described with qPCR. Environmental Microbiology 9, 2162-2174.

Spring, S., AmANn, R., LudWIG, W., Schleifer, K.H., VAN GEMERDEN, H., PETERSEN, N. (1993) Dominating role of an unusual magnetotactic bacterium in the microaerobic zone of a freshwater sediment. Applied and Environmental Microbiology 59, 2397-2403.

Tarayre, C., Nguyen H.T., Brognaux, A., Delepierre, A., De Clerce, L., Charlier, R., Michels, E., Meers, E., Delvigne, F. (2016) Characterization of Phosphate Accumulating Organisms and Techniques for Polyphosphate Detection: A Review. Sensors 16, 797. 